\title{
Study on Internet Investor Relations Management Evaluation of Listed Companies in China
}

\author{
Ping Guan ${ }^{1,2}$, Liangrong Song ${ }^{1} \&$ Haimin $\mathrm{Cao}^{2}$ \\ ${ }^{1}$ School of Management, University of Shanghai for Science and Technology, Shanghai, China \\ ${ }^{2}$ School of Management, Shanghai University of Engineering Science,Shanghai, China \\ Correspondence: Guan Ping, School of Management, Shanghai University of Engineering Science, Shanghai, 333 \\ Dragon Road, Songjiang District, China
}

Received: November 25, 2015

Accepted: December 29, 2015

Online Published: January 12, 2016

doi:10.5430/afr.v5n1p121

URL: http://dx.doi.org/10.5430/afr.v5n1p121

Project funding: School Fund (p201503001)

\begin{abstract}
Network technology has an important influence on internet investor relations management in the information age. This paper selects the top 100 listed companies as samples, construct the evaluation index system of internet investor relations management from three dimensions, such as information technology, information disclosure and investor interaction. The research shows that: the level of internet investor relations management in china is still low; there are apparent differences between companies. Network technology, the voluntary disclosure information and investor communication aspects need to be improved, investor relations website needs to be strengthened. Finally, the paper put forward some suggestions.
\end{abstract}

Keywords: Internet investor relations management, Information disclosure, Information technology, Investor interaction

\section{Introduction}

As one of the main research directions of corporate governance, investor relations management originated in the western mature capital market, which benefited from the promotion of the establishment of the association of investor relations and evaluation institutions, and had achieved a wealth of research results in the past 20 years. Effective investor relations activities and management can improve corporate governance, reduce financing costs, improve the level of information disclosure, enhance the positive interaction with investors and realize the maximization of enterprise value, which had been confirmed by many scholars at home and abroad.

In 2005, China issued "Listing Corporation and Investor Relations Work Guidelines": The company should pay attention to the construction of network communication platform, investor relations column can be set up in the company's website; should enrich and update the company website content, such as press release, company profile, business product or service information, legal information disclosure, investor contact way, special articles, administrative personnel, real-time stock quotes and other related information. With the rapid development of network technology and social media, internet investor relations activities and management will become a new research area. The paper evaluates the lever of China's internet investor relations management and put forward some suggestions.

Internet investor relations management level is closely related to network information technology, network information disclosure and investor interaction, so the paper construct the evaluation index system from above three aspects. The structure of the paper is divided into three parts, the first part is the literature review, the second part is the internet investor relations management evaluation, including evaluation index, sample selection, reliability analysis and data evaluation, the third part is the problems and countermeasures.

\section{Relevant Research Status and Review}

Internet investor relations management (IIRM) is developed on the basis of the concept of IRM and IR, which mainly refers to the information disclosure and communication activities, work and management based on the internet. 
The early research on the Internet Investor Relations Management focused on the investigation about level of investor relations website and impact factors. Listed companies website is more powerful than traditional media information content, to a certain extent, also reflects listing corporation's image, often have its unique value and advantages. Hedlin (1999) investigated the use of the internet to carry out the activities of the investors and put forward the three stages of the development of the website. Deller et al. (1999) selected the stock market S\&P, FTSE, DAX 100 index and compared the United States, Britain, Germany's website investor relations management status, and listed some of the details of the website construction projects. Geerings et al. (2003) chose three countries of Belgium, France, Holland, the 50 largest listing corporations to investigate, and used three stages of the development of the website model for the comparison. Bollen et al. $(2006,2008)$ investigated the 270 listing corporation from Australia, Belgium, France, Holland, South Africa and the United Kingdom, found that the 29 evaluation index of the company size, international level, the proportion of individual investors, information disclosure environment had an important impact on the internet investor relations management, and pointed out the importance of the website design. Hao Chen (2005) on the chinese 400 listed companies website investor relations column evaluation, given the company information, information disclosure, corporate governance, investor analysis and research, media reviews, investor contact and communication, investor service 7 project content website investor relations column. Lin Bin et al. (2005) chose Shenzhen listing corporation website as the research samples, discussed the influence factors of investor relations management, through the establishment of information content, investor support for the two major categories of 48 indicators of the website investor relations management index, empirical test of the company's scale, corporate performance, institutional investors, refinancing plan, the proportion of shares have an important influence on internet investor relations management. Subsequently, many scholars at home and abroad began to carry out the empirical analysis about the correlation between internet investor relations management and financing motivation, financing costs, operating performance.

Internet investor relations management is closely related to the disclosure of information. Information disclosure is considered as a core component of the internet investor relations management. Internet financial report (IFR) is a new type of financial reporting in the information technology environment, making the financial report information more timely and transparent. In 1995, the United States Securities and Exchange Commission (SEC) required listing corporation to submit the electronic documents of general financial reports to EDGAR system. In 2000, China put forward the request of the electronic information disclosure, and in 2005, we made the "Listing Corporation Information Disclosure Standard", online electronic financial report has a certain content and format requirements. Ashbaugh (1999) and Debreceny (2002) et al. studied the characteristics and influence factors of internet financial report. Lymer and Xiao $(2002,2004)$ found that more and more companies began to pay attention to information technology, and to predict internet financial reporting system will be standardized (general purpose) and the customer (on demand) the trade-off between. Kelton et al. $(2008,2012)$ studied the important influence of corporate governance on the information disclosure behavior of internet financial reporting. In recent years, XBRL technology has become a new network financial reporting language. Nie Ping (2011) compared with the XBRL demonstration service platform, which are set up by the Securities and Exchange Commission, the Shanghai stock exchange, the Shenzhen stock exchange, the Israel securities exchange, select two major categories of information disclosure effectiveness, the website's 12 major categories of indicators of XBRL network financial reporting, analysis and evaluation. Wang Hailin et al. (2012) selected the manufacturing and information technology industry listing corporation website as samples, established general information, financial and related information, disclosure form, tools, disclosure channels and security of a total of 91 indicators of internet financial reporting system was evaluated. At the same time, the era of big data security issues network should strengthen the supervision of information disclosure.

In the comparative study, Wan Xiaowen (2010) discussed the research status of the internet investor relations management between the Western and China. Feng Yanjie et al. (2014) to from the DJIA 30 companies, FTSE 30 companies, HSI48 companies, domestic CNINFO Index 40 companies, selected the company profile, corporate governance, convenient tool for users, financial and operational information disclosure, stock information, results, news release and other meetings, shareholder services of 76 indicators on the Chinese mainland, Hong Kong, US, UK listed companies internet investor relations management comparative analysis of the data. With the rapid development of network information technology, investor relations and interactive research has become a new perspective, Ma Lianfu et al. (2014) selected the network communication as the five dimensions of the interactive index system.

Through the review of previous literature, from the perspective of network information development and governance, the evaluation factors of internet investor relations management are summarized as network information technology, 
network information disclosure, network interactive communication three aspects, investor relations website (or corporate website investor relations column) design is an important factor affecting the level of internet investor relations management. Therefore, this article constructs the index system from above three dimensions to evaluate the level of internet investor relations management.

\section{Internet Investor Relations Management Evaluation}

\subsection{Evaluation Index}

Internet investor relations management evaluation is more mature in foreign countries, American Investor Relations Association, British Investor Relations Association, IR web report, IR magazine and other associations and rating agencies have their own evaluation criteria, such as Web IR report from investor relations online management level to evaluate and award; IR society from the annual report of the company, company website, information online, company governance to evaluate and award. After the promulgation of the guidelines in china, the domestic listing corporation have begun to set up the investor relations column in its website, communicate with investors, after nearly 10 years of development, many listing corporations have realized the strategic value of website management.

Based on the evaluation index system of investor relations management, this paper constructs the information technology, information disclosure, interactive communication three dimensions, two levels of multi-dimensional internet investor relations management evaluation index system, a total of 30 indicators, specifically see table 1 . In the selection of indicators, the comprehensive consideration of the representative of the index, the importance of the index, and the use of the enterprise. The first dimension is the index of information technology, which reflects the situation of the application of listing corporation website construction and information technology in the information age. Network information and interaction should take into account the convenience of information knowledge acquisition, management and operation of the convenience and ease of control operation. Second dimension is the index of information disclosure, which reflects the information disclosure and information sharing, including legal information disclosure and voluntary information disclosure. Third dimension is the index of interactive communication, which reflects ways and methods of communicate. China's information disclosure system require that listed companies must disclose the information in the designated media (stock exchange website, designated newspapers and designated website), but also in other media (company website), but disclosure time of other media should not be earlier than the designated media, disclosure context of other media are not more than the designated media. Therefore, this paper is based on the company's website, and takes into account stock exchange website and designated website. 
Table 1. Evaluation index of internet investor relations management

\begin{tabular}{|c|c|c|}
\hline Dimensions & Index classification & Specific index \\
\hline \multirow{13}{*}{ Information technology } & \multirow{6}{*}{ Website construction } & Website \\
\hline & & Picture and text image \\
\hline & & Investor relations column \\
\hline & & Column design clear \\
\hline & & English website \\
\hline & & Official website certification \\
\hline & \multirow{7}{*}{ Technical tool } & Station search engine \\
\hline & & Website map or navigation \\
\hline & & Link \\
\hline & & Hyperlink \\
\hline & & Download tool \\
\hline & & XBRL \\
\hline & & On-line analysis tool \\
\hline \multirow{11}{*}{ Information disclosure } & \multirow{4}{*}{ Statutory disclosure } & Company announcement \\
\hline & & Periodic report \\
\hline & & Annual report \\
\hline & & Timely annual report \\
\hline & \multirow{7}{*}{ Voluntary disclosure } & $\begin{array}{l}\text { Corporate governance and capital } \\
\text { structure }\end{array}$ \\
\hline & & Stock quotes and information \\
\hline & & Financial summary \\
\hline & & Dividend distribution \\
\hline & & English annual report \\
\hline & & Social responsibility report \\
\hline & & Analyst report \\
\hline \multirow{6}{*}{ Interactive communication } & \multirow{3}{*}{ Static communication } & Investor phone and mail \\
\hline & & Investor message and feedback \\
\hline & & Frequently asked questions and answers \\
\hline & \multirow{3}{*}{ Dynamic communication } & Performance roadshow \\
\hline & & Investor interactive platform \\
\hline & & Network investor activity \\
\hline
\end{tabular}

\subsection{Sample Selection, Reliability Analysis and Data Evaluation}

\subsubsection{Sample Selection}

In this paper, we select the "China Economic Yearbook - listing Corporation evaluation volume" (2013) in the 100 performance of the listing corporation as samples to evaluate the level of internet investor relations management in China, see table 2. Through the search for the website, and in 2014(Nov and Dec) to visit the company's website, to ensure the accuracy of the index data, in the course of the investigation conducted a three review, all data through manual investigation and collection. At the same time, according to the industry classification of Listed Companies Guidelines (2012 Revision) and 2014 4th of listed company industry classification results and statistics, 19 industry categories covering rate was $74 \%$, nearly $50 \%$ of the enterprises from Shanghai and Shenzhen 300 index and the huge influx of 100 index ,these enterprises have certain representativeness. 
Table 2. Top 100 listed companies websites of China

\begin{tabular}{|c|c|c|c|}
\hline Stock code & company websites & Stock code & company websites \\
\hline 601633 & http://www.gwm.com.cn & 600048 & http://www.poly.com.cn \\
\hline 000651 & http://www.gree.com.cn & 002051 & http://www.camce.com.cn \\
\hline 600016 & http://www.cmbc.com.cn & 000863 & http://www.sanxiang-sh.com \\
\hline 600690 & http://www.haier.net/cn & 002285 & http://www.worldunion.com.cn \\
\hline 600578 & http://www.jingnengpower.com & 600383 & http://www.gemdale.com \\
\hline 600036 & http://www.cmbchina.com & 600362 & http://www.jxcc.com \\
\hline 600519 & http://www.china-moutai.com & 000669 & http://www.spjhe.com \\
\hline 600309 & http://www.ytpu.com & 600199 & http://www.jzz.cn \\
\hline 601398 & http://www.icbc.com.cn & 600276 & http://www.hrs.com.cn \\
\hline 000006 & http://www.zhenye.com & 600763 & http://www.tcmedical.com.cn \\
\hline 000858 & http://www.wuliangye.com.cn & 600315 & http://www.jahwa.com.cn \\
\hline 601888 & http://www.citsgroup.net & 000157 & http://www.zoomlion.com \\
\hline 600104 & http://www.saicgroup.com & 603366 & http://www.solareast.com \\
\hline 002146 & http://www.risesun.cn & 601808 & http://www.cosl.com.cn \\
\hline 000568 & http://www.lzlj.com & 600585 & http://www.conch.cn \\
\hline 601939 & http://www.ccb.com & 600028 & http://www.sinopec.com \\
\hline 601088 & http://www.shenhuachina.com & 600348 & http://www.ymjt.com.cn \\
\hline 600547 & http://www.sd-gold.com & 002063 & http://www.ygsoft.com \\
\hline 002415 & http://www.hikvision.com & 601668 & http://www.cscec.com.cn \\
\hline 600403 & http://www.hndyny.com & 600887 & http://www.yili.com \\
\hline 000895 & http://www.shuanghui.net & 600017 & http://www.chinanetcenter.com \\
\hline 600809 & http://www.fenjiu.com.cn & 000786 & http://www.bnbmg.com.cn \\
\hline 601877 & http://www.chint.net & 600098 & http://www.gdih.cn/cn \\
\hline 600489 & http://www.zjgold.com & 601857 & http://www.cnpc.com.cn \\
\hline 000979 & http://www.zhonghongholdings.com & 600216 & http://www.china-zmc.com \\
\hline 002304 & http://www.chinayanghe.com & 000562 & http://www.hysec.com \\
\hline 601117 & http://www.cncec.com.cn & 600637 & http://www.bestv.com.cn \\
\hline 600741 & http://www.huayu-auto.com & 002572 & http://www.sogal.com.cn/ \\
\hline 601006 & http://www.daqintielu.com & 000008 & No website \\
\hline 600066 & http://www.yutong.com & 000537 & No website \\
\hline 002385 & http://www.dbn.com.cn & 000423 & http://www.dongeejiao.com \\
\hline 000791 & http://www.gepic.cn & 000552 & http://www.jymdgs.com \\
\hline
\end{tabular}




\begin{tabular}{|c|c|c|c|}
\hline 002142 & http://www.nbcb.com.cn & 600897 & http://www.xiac.com.cn \\
\hline 000002 & http://www.vanke.com & 600004 & http://www.gbiac.net \\
\hline 601166 & http://www.cib.com.cn & 002344 & http://www.chinaleather.com \\
\hline 000011 & http://www.szwuye.com.cn & 002241 & http://www.goertek.com \\
\hline 600658 & http://www.bez.com.cn & 600395 & http://www.pjgf.cn \\
\hline 000538 & http://www.yunnanbaiyao.com.cn & 002588 & http://www.stanleygroup.cn \\
\hline 600684 & http://www.gzprg.com.cn & 002038 & http://www.slpharm.com.cn \\
\hline 601899 & http://www.zjky.cn & 000888 & No website \\
\hline 000042 & http://www.cctzkg.com & 600694 & No website \\
\hline 000539 & http://www.ged.com.cn & 600085 & http://www.tongrentang.com \\
\hline 000069 & http://www.octholding.com & 601009 & http://www.njcb.com.cn \\
\hline 002081 & http://www.goldmantis.com & 600340 & http://www.cflden.com \\
\hline 000999 & http://www.999.com.cn & 002186 & http://www.quanjude.com.cn \\
\hline 600600 & http://www.1903beer.com & 600271 & http://www.aisino.com \\
\hline 600863 & http://www.nmhdwz.com & 600060 & http://hxdq.hisense.com \\
\hline 600039 & http://www.scrbg.com.cn & 002470 & http://www.kingenta.com \\
\hline 600900 & http://www.cypc.com.cn & 600347 & http://www.tigermed.net \\
\hline 002700 & No website & 002400 & http://www.gdadc.com \\
\hline
\end{tabular}

\subsubsection{Reliability Analysis}

Cronbach's alpha coefficient test is the most common method for the analysis of the reliability analysis of the index system, which is the reliability analysis method of social science research. The formula for the calculation of Cronbach's alpha coefficient is as follows:

$$
\alpha=(\mathrm{n} / \mathrm{n}-1)\left(1-\sum \mathrm{S}_{\mathrm{i}} / \mathrm{S}_{\mathrm{t}}\right)
$$

Referring to the existing literature, in the reliability analysis, each index was set to 1 point, all of the same weight. Through calculation, the evaluation index system of internet investor relations management is 0.8122 , the reliability test of the index is a good evaluation of the project scale. In the use of the reliability analysis of Cronbach's alpha coefficient, we should pay attention to the following aspects: 1. Cronbach alpha coefficient for the number of indicators have certain requirements. 2. Cronbach alpha coefficient is affected by index properties and internal consistency.

\subsubsection{Data Evaluation}

According to the above index system, internet investor relations management level of top 100 were investigated, and the results are shown in table 3 and table 4 . Internet investor relations management index system overall completion rate is $52.97 \%$; completion rate of good indicators are statutory disclosure, website construction index, completion rate of poor indicator indicators are dynamic communication, voluntary disclosure index. Index completion rate of $60 \%$ of the listing corporation has $38 \%$, the highest rate is $83.33 \%$, the lowest rate is $10 \%$, the industry's highest score is financial industry, the average completion rate is $66.67 \%$; the lowest score is wholesale and retail industry, the average completion rate is $11.67 \%$. The survey found that the international background of the listing corporation's internet investor relations management level are higher, the use of advanced internet technology to optimize website content, can actively carry out internet investor relations activities, the establishment of official microblogging, micro channel and other communication channels, but some listing corporation only meet the basic requirements of regulations and guidelines. 
Table 3. Completion rate statistics of the dimension

\begin{tabular}{|c|c|c|c|c|c|}
\hline Index latitude & Index classification & $\begin{array}{l}\text { Index } \\
\text { terms }\end{array}$ & $\begin{array}{l}\text { Sample } \\
\text { quantity }\end{array}$ & $\begin{array}{l}\text { Index total } \\
\text { score }\end{array}$ & $\begin{array}{c}\text { Index } \\
\text { completion rate }\end{array}$ \\
\hline \multirow{2}{*}{$\begin{array}{l}\text { Information } \\
\text { technology }\end{array}$} & Website construction & 6 & 100 & 458 & $76.33 \%$ \\
\hline & Technical tool & 7 & 100 & 358 & $51.14 \%$ \\
\hline \multirow{2}{*}{$\begin{array}{l}\text { Information } \\
\text { disclosure }\end{array}$} & Statutory disclosure & 4 & 100 & 359 & $89.75 \%$ \\
\hline & Voluntary disclosure & 7 & 100 & 235 & $33.57 \%$ \\
\hline \multirow{2}{*}{$\begin{array}{l}\text { Interactive } \\
\text { communication }\end{array}$} & Static communication & 3 & 100 & 106 & $35.33 \%$ \\
\hline & Dynamic communication & 3 & 100 & 73 & $24.33 \%$ \\
\hline Total & & 30 & 100 & 1589 & $52.97 \%$ \\
\hline
\end{tabular}

Table 4. Completion rate statistics of the industry

\begin{tabular}{lccrc}
\hline \multicolumn{1}{c}{ Industry } & $\begin{array}{c}\text { Index } \\
\text { terms }\end{array}$ & $\begin{array}{c}\text { Sample } \\
\text { quantity }\end{array}$ & $\begin{array}{c}\text { Index total } \\
\text { score }\end{array}$ & $\begin{array}{c}\text { Index } \\
\text { completion rate }\end{array}$ \\
\hline Mining industry & 30 & 11 & 186 & $56.36 \%$ \\
Manufacturing industry & 30 & 40 & 634 & $52.83 \%$ \\
Electricity, heat, gas and water production and & 30 & 6 & 88 & $48.89 \%$ \\
supply industry & & & 79 & $52.67 \%$ \\
Construction industry & 30 & 5 & 7 & $11.67 \%$ \\
Wholesale and retail & 30 & 2 & 48 & $53.33 \%$ \\
Transportation, storage and postal services & 30 & 3 & 16 & $53.33 \%$ \\
Accommodation and catering industry & 30 & 1 & 49 & $54.44 \%$ \\
Information transmission, software and & 30 & 3 & 160 & $66.67 \%$ \\
information technology services & & & 211 & $50.24 \%$ \\
Finance & 30 & 8 & 53 & $58.89 \%$ \\
Estate & 30 & 14 & 28 & $46.67 \%$ \\
Leasing and business services & 30 & 3 & & \\
Water conservancy, environment and public & 30 & 2 & 15 & $50 \%$ \\
facilities management & & & 15 & $50 \%$ \\
Health and social work & 30 & 1 & 1589 & $52.97 \%$ \\
Scientific research and technical services & 30 & 1 & 100 & \\
$\quad$ Total & 30 & & & \\
\hline
\end{tabular}

\section{Conclusion}

\subsection{Problems}

\subsubsection{Internet Investor Relations Management Level Is Low}

Listing corporation's internet investor relations management level is still low in China. In the aspect of information technology, although the company's website has been gradually built, but in the use of technical tool, such as website research, site navigation, hyperlinks and other tools need to be improved; XBRL technology in the domestic application is not mature, mainly concentrated in Shanghai and Shenzhen Stock Exchange, XBRL technology and online analysis tools are rarely available in the company's website. In aspect of information disclosure, the company announcement, periodic report of the statutory information disclosure content is more standardized, but the voluntary exchange of information is clearly insufficient, from the analysis of the internal management of the company's recommendations, strategic forecasts and external analysts and investors to share the report. In addition, company's website is not too much emphasis on the timeliness. In the aspect of interactive communication, the more common is 
the telephone, mail, message, Q\&A and other static communication ways, in addition to the Stock Exchange Shanghai E-interaction, the Shenzhen stock exchange the interaction create interactive platform, most enterprises did not build investor communication system and platform, and rarely for small investors to participate in, such as the network voting system for shareholders, network video of shareholders meeting.

\subsubsection{Internet Investor Relations Management Level Is Different}

There is a significant difference in the level of internet investor relations management between companies. The survey found that the international background of the listing corporation can better use the network technique to optimize the site content design and arrangement, some enterprises also opened the official micro blog, micro channel and other communication channels to communicate with investors, share continuous social responsibility report, analysts report and management report and other information, establish a good corporate image. But there are a number of listing corporation to meet the basic requirements of regulations and guidelines, website construction is simple, the lack of investor relations management, do not attach importance to the interaction with investors on the network platform. The reasons for the difference between companies are different understanding of the importance and necessity of internet investor relations management. On the other hand, it also reflects the lack of standard.

\subsection{Suggestions}

Internet investor relations management is considered to be a voluntary, proactive strategic management activities, to enhance the level of internet investor relations management, the enterprise itself should be conscious behavior, but to promote the listing corporations to implement internet investor relations management, need for the securities market parties to continue to work hard. First of all, we should actively learn from advanced enterprises, and constantly organize the authority to evaluate the level of internet investor relations management, and timely publish the best practice of investor relations management based on the internet, push the enterprise's own to strengthen internet investor relations management, enhance the initiative of enterprise value. Secondly, we should speed up the construction of internet investor relations management work of the construction standards and related specifications, let the stock exchange website, interactive platform, company website, financial website, social media play different functions, to build a multi-level internet investor relations management system.

In the future, the stock issuance system will be changed from the approved system to the registration system, the main responsibility of the IPO listing corporation and the professional quality of investors, the role of full disclosure and full communication will become more prominent. This paper mainly carries on the research of internet investor relation management, but mobile internet technology will become the main channel for information communication, the development of social network platform is about to have an important impact on investor relations management, so there is much room for further research regarding the issue. Regulatory authorities should accelerate the healthy development of internet investor relations management, better protect the interests of investors, especially public investors.

\section{References}

Andrea Seaton Kelton, Robin R. (2012). Pennington.Internet Financial Reporting: The Effects of Information Presentation Format and Content Differences on Investor Decision Making. Computers in Human Behavior, 28(4), 1178-1185. http://dx.doi.org/10.1016/j.chb.2012.01.028

Andrea Seaton Kelton, Yawen Yang. (2008). The impact of Corporate Governance on Internet Financial Reporting. Journal of Accounting and Public Policy, 27(1), 62-87. http://dx.doi.org/10.1016/j.jaccpubpol.2007.11.001

China Securities Regulatory Commission. (2005). Listing Corporation and investor relations work guidelines,http://www.csrc.gov.cn/pub/newsite/flb/flfg/bmgf/ssgs/gszl/201012/t20101231_189739.html [EB/OL]. [2005-07-11].

Development Research Center of the State Council. China Economic Yearbook - Listing Corporation Evaluation Volume. Beijing: China Economic Yearbook, 2013.

Dominic Deller, Michael Stubenrath, Christoph weber. (1999). A survey on the use of the Internet for investor relations in the USA, the UK and Germany. The European Accounting review, 8(2), 351-364. http://dx.doi.org/10.1080/096381899336087

Feng Yanjie, Xu Bo. (2014). Comparative study on Internet Investor Relations Management. Securities market Herald, (1), 33-39.

Hao Chen, Li li. (2005). Empirical Research on China's Listing Corporation Website Investor Relations Column. management science, 18(1), 56-61. 
Hollis Ashbaugh, Karla M. Johnstone \& Terry D. Warfield. (1999). Corporate Reporting on the Internet. Accounting Horizons, 13(3), 241-257. http://dx.doi.org/10.2308/acch.1999.13.3.241

J.Geerings, L.H.H.Bollen, H.F.D. Hassink. (2003). Investor relations on the Internet: a survey of the Euronext zone. The European Accounting Review, 12(3), 567-579. http://dx.doi.org/10.1080/0963818032000083531

Laury Bollen, Harold Hassink, Gordana Bozic. (2006). Measuring and Explaining the Quality of Internet Investor Relations Activities: A Multinational Empirical Analysis. International Journal of Accounting Information Systems, 7(4), 273-298. http://dx.doi.org/10.1016/j.accinf.2006.04.005

Laury H.Bollen, Harold F. Hassink, Rindert K. de Lange, Saskia D. Buijl. (2008). Best practices in managing investor relations websites: directions for future research. Journal of Information System, 22(2), 171-194. http://dx.doi.org/10.2308/jis.2008.22.2.171

Lin bin, Xin Qingquan, Yang Deming. (2005). Investor Relations Management and Its Influence Factors -- Based on Shenzhen Listed Companies Empirical Research. Accounting research, (9), 32-38.

M. Ettredge, V.J. Richardson, S. Scholz. (2002). Dissemination of information for investors at corporate Web sites, $J$ Account Public Policy, 357-369.

Ma Lianfu,Shen Xiaoxiu, Wang Yuanfang. (2014). Research on Investor Relations Index and Its Applications. Forecast, 33(1), 39-44.

Michael John Jones, Jason Zezhong Xiao. (2004). Financial Reporting on the Internet by 2010: A Consensus View, Accounting Forum, 28(3), 237-263. http://dx.doi.org/10.1016/j.accfor.2004.07.002

Nie Ping, Zhou Dai. (2011). Based on the XBRL Environment Internet Financial Report Web Presentation Quality Empirical Research. Accounting research, (4), 8-14.

Pontus Hedlin. (1999). The Internet as a Vehicle for Investor Relations: The Swedish Case. The European Accounting Review, 8(2), 373-381. http://dx.doi.org/10.1080/096381899336104

Roger Debreceny, Glen L.Gray, Asheq Rahman. (2002). The Determinants of Internet Financial Reporting Original Research Article. Journal of Accounting and Public Policy, 21(4-5), 371-394.

Wan Xiaowen, Xu Chunjie. (2013). A Review of the Research on Internet Investor Relations Management of Western. Journal of Nanjing Audit University, (6), 10-16.

Wang Hailin, Zhang Shujuan. (2012). Research on the Evaluation of Internet Financial Reporting System of Listing Corporation. Audit research, (5), 76-84.

Zezhong Xiao, Michael John Jones, Andy Lymer. (2002). Immediate Trends in Internet Reporting. European Accounting Review,11(2), 245-276. http://dx.doi.org/10.1080/09638180020017087a 